ISSN 2411-4758 (Print) 2518-1602 (Online)

Native word in ethnocultural dimension, Drohobych, Posvit, 2021, pp. 33-41.

DOI: https://doi.org/10.24919/2411-4758.2021.211704

УДК 78.071 .2

\title{
ЗНАК ЯК УНІВЕРСАЛЬНИЙ ІНСТРУМЕНТ МОВНОЇ ІДЕНТИЧНОСТІ ЕТНОСУ
}

Ріма КАЛЬКО, кандидат педагогічних наук, доцент кафедри перекладу та іноземних мов Національної Металургійної Академії Украӥни (Україна, Дніпро) kalkorita1970@gmail.com

ORCID: http://orcid.org/0000-0002-7895-7078/

Research ID: https://publons.com/researcher/3873863/rita-kalko/

Статтю подано до редколегіi//The article is submitted to the editorial board:11.09.2020.

Статтю опубліковано/The article is published: 22.02.2021.

У статті розглянуто питання про знак як універсальний інструмент мовної ідентичності етносу. Авторуказуєна особливостірозвиткузнакавісторіїсеміотики. Охарактеризовано поняття знака та символу. Висвітлено систему принципів мислення найдавніших циивілізацій, поступово перетворену у фіксовані зображсення писемних знаків для передачі звучання тих або тих фонетичних чи значущих мовних одиниць. Давні системи письма дають підстави розглядати їхнє виникнення як закономірний підсумок розвитку людського суспільства на певній стадії формування найдавніших извілізацій. Акцентовано увагу на китайській ієрогліфічній писемності, яка протягом усього свого існування зберігає самобутні риси через відтворення візуальних образів. Доведено, щуо теорія семіотики в історичному аспекті дає можливість пізнати знак у момент не лише його використання, але й усвідомлення певними спільнотами чи етносами, а також окреслити його тематичне розуміння в конкретний історичний період. Використання знаків китайської класичної мови в такому контексті може допомогти в дешифруванні невідомих текстів.

Ключові слова: знак; етнос; мовна ідентичність; універсальний інструмент; семіотика; ієрогліфічна писемність.

\section{SIGN AS A UNIVERSAL TOOL OF ETHNOS' LINGUISTIC IDENTITY}

\section{Rita KALKO,}

Ph.D. in Pedagogy, associate professor of Translation and Foreign Languages Department National Metallurgical Academy of Ukraine, (Ukraine, Dnipro) kalkorita1970@gmail.com 
The article discusses the issue of a sign as a universal instrument of the linguistic identity of an ethnic group. The purpose of the article is to prove that the study of the principles of thinking of local civilizations recorded in symbolic visual images is possible by studying these systems of signs. The author points out the peculiarities of the development of the sign in the history of Semiotics. The concept of sign and symbol as one of the universal tools is characterized. The system of principles of thinking of the most ancient civilizations, which gradually turned into a fixed symbolic image of written signs, for recording the sound of certain units of language, or certain significant linguistic units, is covered. A large number of examples of ancient writing systems give reason to consider their emergence as a natural result of the development of human society at a certain stage of the formation of ancient civilizations. Attention is focused on the Chinese hieroglyphic writing, which throughout its existence retains ethnogenetic distinctive features through the reproduction of visual images. It has been proved that the theory of Semiotics in the historical sense makes it possible to cognize a sign at the moment, not only its use, but also its awareness by certain communities or ethnic groups, outlining its thematic understanding at a certain historical stage. The use of Chinese classical characters in this context can help in deciphering unknown texts.

Key words: sign, ethnos, linguistic identity; universal tool; semiotics, hieroglyphic writing.

Постановка проблеми. Теорія семіотики дає можливість пізнати знак не тільки в момент його використання чи усвідомлення певними історичними спільнотами або ж етносами через окреслення змісту, але також під час тлумачення його ролі, здійснюваного лише в конкретному відношенні. Установлено, що доцільність досвіду - від походження в почуттях до найвищих точок розуміння - можна визначити за допомогою знаків. Звідси випливає, що історія семіотики простежуватиметься в напрямах, які ведуть до того моменту, коли усвідомлена загальна й усебічна роль знака у визначенні накопиченого досвіду й знання. Окреслену проблему розробляли багато видатних лінгвістів, культурологів і філософів (Аристотель, І. Арнольд, Н. Арутюнова, Е. Кант, Е. Касірер, Дж. Локк, О. Лосєв, М. Лотман, М. Мамардашвілі, Ч. Пірс, Дж. Поінсот, О. Потебня, К. Юнг та ін.). Проте найбільш докладно іiі можна розглянути в контексті семіотики, яку розуміють як загальну теорію знака, що розглядає специфіку окремих знакових систем та їх функціонування. Серед прихильників цього напряму доречно відмітити таких учених, як Ф. де Соссюр, В. Гумбольдт, В. Фортунатов, О. Потебня, Б. де Куртене, В. Богородицький та ін. 
Аналіз досліджень. Дослідження праць мислителів античного світу вказують на те, що одним із перших, хто сформулював свої погляди про Знак (Signum) як універсальний інструмент або засіб, за допомогою якого здійснюють повідомлення [communication] будь-якого виду чи рівня, був Бл. Августин. Він уперше запропонував «загальну семіотику», тобто загальну «науку», або «доктрину про знаки», де знаки стають Родом [Genus], у якому Слова [Onomata] і Природні симптоми [Semeia] $є$ уподібненнями, рівними видові. Хоч, як зазначають дослідники (Дж. Ділі, У. Еко, Р. Ламбертіні), за часів, коли панувала грецька філософія, не було такого поняття, як «знак», яке б відповідало сьогоднішньому поняттю, тобто яке ми сприймаємо як належне і яке завдяки семіозу уніфікує предмет або об'єкт семіотичного дослідження (Ділі, 2000, с. 164). Б. Вільямс робить висновок, що «від античних часів до сучасності в усіх трактатах про знак його розглядали як «маску Януса», тобто «подвійно»: або відносно до когнітивної снаги самого організму, або відносно до позначуваного змісту. Якщо взяти до уваги таку відмінність, то «проблема правдивої основи» доктрини про знаки буде така: «У чому ж полягає відносна сутність позначування?» (Ділі, 2000 , c. 167).

У семіотичному дискурсі поняття «знак» $є$ універсальним елементом бачення, а символ - його особливим різновидом, специфіка якого полягає непрямому, умовному характері зв'язку між означуваним і означником, позаяк знак - універсальний складник усякої мовної системи, що не відрізняє одні мови від інших, а об'єднує їх. Для позначення знаків найдавніших систем письма використовують різні терміни. Наприклад, термін «ієрогліф» (від гр. Hieros 'священний' і glyphe 'те, що вирізано') став використовуватися для знаків архаїчних систем писемності у вигляді малюнків (піктограм), а також для літер або символів із прихованим символічним значенням; на позначення близькосхідних клинописних знаків, видряпаних на глиняних табличках, або знаків китайської протоінської цивілізації, що збереглися у вигляді гравюр на керамічних посудинах. Давні греки так називали знаки письма, вирізані на монументальних будівлях Античного Сгипту. Геродот (V ст. до н. е.) використовував для такого письма назву «Hira grammata» ('священні літери'). Можливо, саме такий характер мали таємничі знаки містеричних культів, за допомогою яких посвячені спілкувались між собою. Саме у вигляді «Glyphe» - знаків, написів і текстів, вирізаних на панцирах, черепах і кістках тварин, на керамічних посудинах і на предметах з каменю, нефриту та яшми, - збереглися до наших днів зразки давньокитайських текстів. «У давнину досконалі провідники, 
непокоїлись, що бамбукові дощечки з їхніми нотатками пропадуть та щезнуть ... і тому вирізали (glyphe) їх на камені та металі...» (Мо-цзи) (Кобзев, 2002, с. 365).

Мета статті - довести, що дослідження принципів мислення локальних цивілізацій, зафіксованих у знакових візуальних зображеннях, можливе шляхом вивчення зазначених систем знаків. Китайська ієрогліфічна писемність зберігає самобутні риси, суть яких - у відтворенні візуальних образів, що передають значення через піктографічний малюнок, і тому може слугувати ключем для розуміння глобальних семіотичних проблем.

Виклад основного матеріалу. Найбільш грунтовно розкривають самобутність класичної китайської мови базисні універсальні категорії китайської класичної мови: «Вень» (文) i «Цзи» (子); «Дао» (道) i «Де» (德), «Інь» і «Ян» (陰 陽). Ієрогліф «Вень» (文) (радикал Кансі 67) характеризується надзвичайно багатою семантикою, на що вказує розмаїття його словникових та етимологічних значень, графічно зафіксованих у найдавніших формах зображення. До перших належать: «знаки, писемність, культура, цивілізованість, громадянський, гуманітарний, просвіта, навчання, література, вишукана словесність, стиль». Щодо етимологічного значення, то ієрогліф «Вень» 文 трактують як «татуювання, узор, орнамент» (Кобзев, 2002, с. 180 - 181). Буквальне значення цього ієрогліфа: 'чоловік, який стоїть зі схрещеними руками, або чоловік з татуюванням на грудях'. У більш широкому значенні «Вень» (文) означає будь-яку виявлену впорядкованість: наприклад, у контексті «живої природи» - це «узори» на шкірах тигрів та леопардів або «знаки тварин та птахів», тобто осмислена інтерпретація системи їхніх слідів - «Чжуан-цзи», розд. 7 (Мудрецы Китая, с. 168). У цьому контексті доречно згадати протоієрогліфи архаїчної китайської писемності, які часто називали «пташиними знаками даосів» (鳥跡). Щодо «неживої природи», то це «знаки неба» (тянь вень), астрономічні об’єкти та явища або «знаки землі» (ді вень), символи «праху земного» - «Чжуан-цзи» розд. 7 (Кобзев, 2002, с. 171). Конфуцій у «Лунь Юй» характеризував «Вень» (文) як культуру, пов'язану з освіченістю, ритуалом, музикою та вважав, що іiі гармонійне поєднання з природною основою є ознакою «шляхетної людини» (цзюнь цзи) (君子) або «досконалої людини» (чен жень) (Кобзев, 2002, с. 181).

Дослідження ієрогліфа «Цзи» (子) розкриває дуже важливий для розуміння цього ієрогліфічного поняття семантичний пласт, вивчення якого в культурно-історичному контексті вносить істотні уточнення в проблему розвитку знакових традицій у Давньому Китаї. Ієрогліф 
«Цзи»子 позначає безтурботність, тишу, спокій. Цей головний компонент пари «Гуй цзи» ('занурення в безтурботність') у китайських словниках трактовано як евфемізм, уживаний на позначення смерті (буддистського) монаха або монахині, тобто спочинку, або успіння, 3 відтінком перевтілення. Але слова «спочити» та «усопнути» прямо не вказують на смерть або небуття, звідси й «Цзи» (子) не має такого значення. У конфуціанських та неоконфуціанських канонах «Лунь Юй» та «Мен Цзи» не виявляємо цього ієрогліфа, але в даоському каноні «Дао Де Цзін» (п. 25) «Цзін» $є$ атрибутом «Дао» (Древнекитайская философия, 1972 - 1973, с. 122). Так, у буддистських текстах ієрогліф «Цзи» (子) співвідноситься з санскритськими термінами «Prasama», «Vivikta», «Santi», які означають «спокій та занурення в нірвану» (Кобзев, 2002 , с. 190 - 191). У китайській етномовній картині світу можна чітко виокремити автентичні та вестернізовані (Індія для Китаю також Захід) концепти. «Цзи» 子 - продукт впливу на китайську свідомість буддистських традицій перевтілення душі, згідно з яким exitus letalis не має трагічного забарвлення, бо душа людини просто змінює тіло.

Дослідження 3 етимології ієрогліфів «Вень» (文) i «Цзи» (子) вказують, по-перше, на розвиток засобів опосередкованої комунікації, пов'язаних із традиціями розфарбовування й татуювання тіл при обрядах ініціації й легітимізації нового суспільного статусу, та на зв'язок образотворчих знаків із набутими іменами (Nomen) людей як засобом соціальної регуляції суспільства. По-друге, простежується чітка графічна вказівка на уявні образи та на їхні лексичні реалізації «Назви» (словник «Шовень цзецзи»), тобто «Вень» (文) пов’ язувалось iз зображенням семантичного поля значень, а «Цзи» (子) - з лексичними значеннями, об’єктивованими в мовленні. Художні знаки «Вень» (文), трансформуючись у свідомості носіїв мови в номінативні знаки, пов'язані зі змістом і зі словами мовлення, перетворювалися в їхні назви - «Цзи» (子).

Характерне для давніх суспільств поняття циклічного часу дає загальну глобальну циклічну модель світобудови, категоризовану в концепцію «Інь-Ян» (陰 陽) - універсальну основу традиційної китайської культури. Стародавні форми накреслення ієрогліфів «Інь» і «Ян» (陰 陽) фіксували прості та водночас фундаментальні речі. Комплекс значень ієрогліфів «Інь» і «Ян» (陰 陽) характеризується контрастом та порівнянням: небо може бути хмарне або сонячне; на землі може бути тінь або світло, холод або тепло, сухо або волого. Як символи природних явищ, ієрогліфи «Інь» і «Ян» 陰 陽 позначали відповідні пори року, а також були символами «Творців» змін на Землі. Біном «Інь-Ян» 
陰 陽 природно співвідноситься 3 іншими китайськими поняттями, наприклад, 3 поняттям, позначуваним ієрогліфом «Ци» (氣) (основна графема - радикал Кансі (气) 84 - Повітря, Газ). У стародавніх формах зображення це символізувало сходження пари до небес, яка збирається там у хмари. Саме туман, що піднімається в Небо й утворює хмари, зафіксований у найдавнішій формі накреслення «дощових хмар» в ієрогліфі «Інь». У контексті китайської філософії ієрогліф «Ци» (氣) став розглядатися як символ двох крайніх фаз процесу перетворення: «Інь» (陰) - хмарне похмуре небо та «Ян» (陽) - чисте, сонячне, а також став узагальнювальною категорією для позначення великої кількості різних феноменів. Отже, концепція «Ян-Інь» (陽陰) відбиває фундаментальні процеси чергування літа й зими, дня й ночі, тепла й холоду, світла й тіні, саме це описують стародавні тексти: «Інь породжує Ян, Ян породжує Інь». Це й відбувається в потоці реального часу, реалізується в зміні днів і ночей, років та зим і графічно відображене на монаді Даоського Кола.

Яскравим прикладом праобразів ієрогліфічних знаків у китайській мові є поняття, позначувані ієрогліфами «Дао» (道) i «Де»(德). Накреслення ієрогліфа «Дао» (道) характеризує зображення того, що і як бачить людина в процесі руху або переміщення. В ієрогліфі «Дао» ( 道 ) відбито зорове сприйняття людиною життєвого простору - фундаментальної умови їі чуттєвого сприйняття, що передує осмисленню й розумінню. Як універсальна основа людського сприйняття, ієрогліф «Дао» (道) може використовуватися як знак загального опису дійсності, а виражене в ньому ядро значень співвідноситися з загальною структурою позиції, яку займає людина у світі. «Дао» (道) й «Де» (德) утворюють корелятивну пару; як одна з найголовніших, найбільш популярних і специфічних категорій, «Дао» (道) має надзвичайно широке коло значень: шлях, підхід, графік, функція, метод, закономірність, принцип, клас, учення, теорія, тлумачення, виклад, мораль правда, абсолют; англ. - way (of action), road, path, reason, principle, truth, doctrine, teaching, absolute; фp. - voie (du devoir), route, mayen; нім. - Sinn. Еквівалентами «Дао» (道) часто вважають Логос і Брахман. У «Дао Де Цзін» «Дао» (道) постає як генетично-організаційна функція єдності щодо «наявності буття та відсутності небуття» (Кобзев 2002, с. 230). У сучасній китайській мові біном «Дао Де» означає мораль, моральність.

Категорія «Де» (德) належить не лише до найдавніших категорій китайської філософії, але й до найдавніших слів китайської писемності. Уже в інських написах присутній цей ієрогліф на ворожильних кістках 
(друга половина II ст. до н. е.). Він має надзвичайно широкий спектр значень: «якість, обдарування, благодать, чесноти, гідність, звитяга, моральна перевага, закономірність» (укр.); «virtue, character, (moral) power, moral force, particular focus, (ouflowino) operation (of the Tao), exemplification of Тао» (англ.); «vertu, beinfaisance, bonte, efficience» (фр.); «Lebenskraft» (нім.). У найзагальнішому розумінні «Де» (德) означає головну якість, що зумовлює найдосконаліший спосіб буття кожної окремої істоти чи речі, тобто індивідуальну благодать, через що нерідко визнається омонімом «Де» (德) - «досягнення, осягнення, здобуття». Оскільки специфіку людини китайські мислителі вбачали здебільшого в іiї здатності дотримуватися належної справедливості «I» (義) та благопристойності - етикету «Лі» (禮), то й людське «Де» (德) розумілося переважно як чесноти, хоч могло позначати й тілесні якості. Як внутрішньо обмежена і природна якість, «Де» (德) становить опозицію до фізичної сили «Лі» (禮), насильства, покарання «Сін» та закону «Фа» (法). Поєднання «У де» - «П’ять благодатей» (五常) 3 часів Цзоу Яня (IV - III ст. до н. е.) стає синонімічним «У сін» - «п’яти елементам» (五行), тобто п’яти універсальним класифікаційним рядам чи фазам, таким, як «Вода», «Вогонь», «Дерево», «Метал», «Земля». Як якість індивідуальна «Де», на відміну від загального й абсолютного Дао - Шляху, є якістю відносною.

У Китаї ієрогліфічне письмо активно використовують із II тис. до н. е. Про це свідчить розвинена система писемності династії Шан-Інь (商殷) (XVI - XII ст. до н. е.), яка включала в себе як мінімум 4971 знак письма (ієрогліфів). Така поважна традиція разом з іншими проблемами об'єктивно-наукового дослідження давньокитайських ієрогліфічних понять актуалізує проблему вивчення й розуміння давньокитайської мови та засобів ії̈ писемної фіксації, на що звернено увагу в численних працях китайських учених-мовознавців - Ма Цзяньчжун, Чи Цзинси, Гао Минкай, Чи Ван та ін. (李少林 2007, с. 294). У процесі еволюції знаків китайської писемності, що мали спочатку виразний графічний характер, «знаки-петрогліфи» залишилися принципово незмінними щодо передачі первісного змісту. Спочатку європейська наука вважала ієрогліфічну писемність засобом консервації архаїчного китайського суспільства під іноземним (маньчжурським) пануванням династії Цін (清 朝) $(1644$ - 1911) та засобом інтелектуального перетворення Китаю на «хвору людину Азії». Більш модерні дослідники відзначають, що принципова незмінність китайської писемності як «значеннєвого» письма протягом усього часу свого побутування зумовлена винятково типологічними особливостями давньокитайської, китайської й групи сіно-ти- 
бетських мов, належних до аморфного або ізолюючого типу. Так, якщо в японській та корейській писемностях, створених на засадах китайської, відбулося доповнення знаків «значеннєвого» письма введенням фонетичних знаків для фіксації морфологічних змін у словах, то китайська мова не погребувала введення додаткових знаків, що й стало найважливішим чинником консервації китайського значеннєвого письма, багато тисяч знаків якого дотепер залишаються незмінними 3 погляду принципів фіксації інформації. Усі спроби створення в Китаї чіткої системи алфавіту були марними, а китайська писемність і в наші дні продовжує зберігатися як значеннєве письмо, або писемність ідеографічного типу, що не виключає використання «спрощених» ієрогліфів. Отже, особливості сіно-тибетських мов, які входять до сіно-тибетської мовної сім'ї, сприяли збереженню в Китаї різних систем знакового письма. Невелика кількість фонетичних знаків для відтворення звуків $\epsilon$ відображенням абетки будь-якої мови в сучасному розумінні, з властивою їй чіткою структурою й доступністю щодо засвоєння та використання знаків у писемності. Усі ці чинники й зумовили витіснення найдавніших систем значеннєвого, або ідеографічного, письма та поширення фонетичних писемностей.

Зазначене вказує на специфічні відмінності давньокитайської й китайської писемної культури від європейських писемних культур, оскільки типу мислення в ієрогліфічних культурах відповідає символьне позначення слів на письмі, яке формує не послідовний текст, а матричний; це необхідно враховувати при вивченні давньокитайської класичної мови. Ієрогліфічні знаки сприймаються цілісно в поєднанні з образом, відтвореним у зображенні.

Висновки та перспективи подальших розвідок. Вивчення принципів мислення найдавніших цивілізацій, поступово перетворених у знакові зображення, передбачає розуміння та необхідність пізнання того, як саме фіксувалися ці знання, що й припускає вивчення систем знаків. Щодо типів писемних знаків, то одні з них слугують для запису звучання фонетичних одиниць мови, інші - для запису певних значущих мовних одиниць, без позначення звукових складників. Існують знаки, які можуть бути цілком не пов'язані 3 мовленням, а тільки передавати у мові зміст, що й було характерною рисою знаків найдавніших систем писемності. Китайська ієрогліфічна писемність протягом усього періоду функціонування зберігає самобутні риси, що полягають у відтворенні візуальних образів, які передають значення зображуваного через піктографічний малюнок. 
Позаяк розвиток засобів фіксації розмовної мови етносів різних культурних ареалів відбувався від ієрогліфічного до фонематичного символу, то використання знаків ізолюючого типу мов, зокрема класичної китайської, може допомогти при дешифруванні невідомих текстів.

\section{СПИСОК ЛІТЕРАТУРИ}

Ділі, Дж. (2000). Основи семіотики. Львів: Арсенал.

Кобзев, А. И. (2002). Философия китайского неоконфуцианства. Москва: Вост. лит.

Тойнбі, А. Дж. (1995). Дослідження історії. Київ: Основи. Т. 2.

Мудрецы Китая. Ян Чжу, Леизы, Чжуанизы. Перевод с китайского Л. Д. Позднеевой. (1994). Санкт-Петербург: «Петербург-ХХІ век», ТОО «Лань». Древнекитайская философия. Собрание текстов : в 2 т. / пер. с кит. сост. Ян Хин-Шун. (1972 - 1973). Москва : Мысль. (Философское наследие).

李少林; 刘正梅. 中国兵法全书. 北京: 北京燕山出版社. 2007年.

\section{REFERENCES}

Dílí, Dzh. (2000). Osnovi semiotiki [Fundamentals of semiotics]. Lviv: Arsenal. [in Ukrainian]

Kobzev, A. I. (2002). Filosofiya kitayskogo neokonfutsianstva [The philosophy of Chinese neo-Confucianism]. Moscow: Vost. lit. [in Russian]

Toynbi, A. Dzh. (1995). Doslidzhennya istorii [History research]. Kyiv: Osnovi. T. 2. [in Ukrainian]

Mudretsy Kitaya. Yan Chzhu, Letszy, Chzhuantszy. Perevod s kitayskogo L. D. Pozdneyevoy [The sages of China. Yang Zhu, Leji, Zhuangzi. Translated from Chinese by L.D. Pozdneeva]. (1994). Sankt-Peterburg: «Peterburg-XXI vek», TOO «Lan». [in Russian]

Drevnekitayskaya filosofiya. Sobraniye tekstov [Ancient Chinese philosophy. Collection of text: in 2 vols.] : v 2 t. per. s kit. sost. Yan Khin-Shun. (1972 - 1973). Moscow : Thought. (Philosophical heritage). [in Russian]

李少林; 刘正梅. 中国兵法全书. 北京: 北京燕山出版社. 2007年. [Li Shaolin; Liu Zhengmei. The Chinese Art of War. Beijing: Beijing Yanshan Publishing House]. [in Chinese]. 